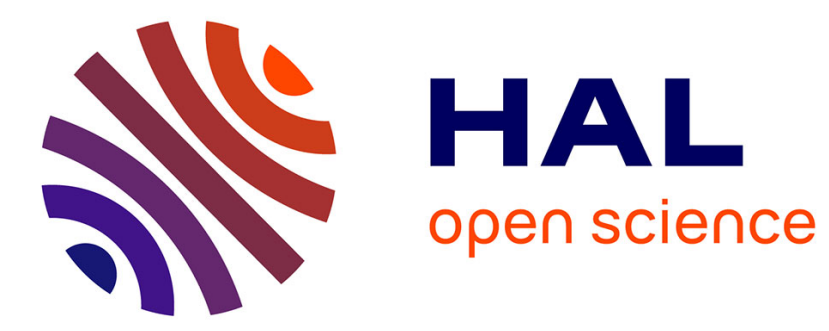

\title{
Consumers' Attitudes Towards Social Media Banking
}

\author{
Dola Majekodunmi, Lisa Harris
}

\section{To cite this version:}

Dola Majekodunmi, Lisa Harris. Consumers' Attitudes Towards Social Media Banking. 15th Conference on e-Business, e-Services and e-Society (I3E), Sep 2016, Swansea, United Kingdom. pp.717-727, 10.1007/978-3-319-45234-0_65. hal-01702171

\section{HAL Id: hal-01702171 \\ https://hal.inria.fr/hal-01702171}

Submitted on 6 Feb 2018

HAL is a multi-disciplinary open access archive for the deposit and dissemination of scientific research documents, whether they are published or not. The documents may come from teaching and research institutions in France or abroad, or from public or private research centers.
L'archive ouverte pluridisciplinaire HAL, est destinée au dépôt et à la diffusion de documents scientifiques de niveau recherche, publiés ou non, émanant des établissements d'enseignement et de recherche français ou étrangers, des laboratoires publics ou privés. 


\title{
Consumers' Attitudes towards Social Media Banking
}

\author{
Dola Majekodunmi ${ }^{1}$, Lisa Harris ${ }^{2}$ \\ ${ }^{1}$ Web Science Doctoral Training Centre, University of Southampton, UK \\ oamlg14@soton.ac.uk
}

${ }^{2}$ Web Science Institute, University of Southampton, UK

l.j.harrisesoton.ac.uk

\begin{abstract}
Social media banking" refers to the use of social media as a form of delivery channel for banking services. This research examines the attitudes and preferences for social media banking among users with emphasis on University of Southampton students. The purpose of the study was to examine the use of social media banking by students using the framework of Rogers Diffusion of Innovation theory and to gain an understanding of the factors which influence the adoption and usage of social media banking. A survey method was used to collect data from a sample of students at the University of Southampton. Data was analysed using an appropriate software which assessed factors that influence the attitude of students to social media banking. These factors were relative advantage, compatibility, complexity, trialability and observability. Descriptive, correlation and multiple regression analysis were used to analyse data. The findings show that three attributes of the diffusion of innovation namely relative advantage, compatibility and trialability were statistically significant in the attitude towards social media banking.
\end{abstract}

Keywords: Innovation $\cdot$ Diffusion $\cdot$ Social media banking $\cdot$ Attitudes $\cdot$ Innovation Adoption $\cdot$ Innovation Attributes

\section{Introduction}

The Web has transformed the nature of banking and the way bank customers access and use their accounts has changed over the years. There are several channels through which banking needs can be met now. Some of these channels are Web enabled which has brought about the concept of social media banking and digital banking. Some banks now use Web 2.0 as a channel for communication, interaction, customer engagement and marketing. Social media banking refers to the use of social media as a form of delivery channel for banking services. This could range from accounts opening, funds transfer, bill payments, as well as customer relationship management, and these activities can be done without visiting a physical branch. Some banks have also referred to this as social banking, Twitter banking and Facebook banking. Some objectives of social media banking include improving customer service, brand and reputation management and product marketing. There are a significant number of social media users (by December 2014, the UK had 57,266,690 internet users out of a total population of $64,767,115$ representing $88.4 \%$ of the population) of which $50.9 \%$ were subscribed to Facebook [10]. However it was reported that even though social media banking adoption by banks is evidenced through their social media pages, sufficient attention has not been given to understanding the role of social media in banking [14] and its impact on attitudes of customers towards its adoption hence the need to investigate the factors that may affect the adoption of social media banking. 
An innovation such as social media banking will usually bring about a change in the different levels of stakeholders be it the bank customer, the organisation offering the idea and the society at large. However as good as an innovation may be, if it is not adopted, it will be categorized as useless. The objective of this study was to investigate factors that influence attitudes towards social media banking. Diffusion of innovations is a theory developed by Everett M. Rogers in 1962 and this theory highlights the need to understand how innovation is accepted. Rogers's theory of diffusion is characterised by five innovation attributes namely relative advantage, compatibility, complexity, trialability and observability and these attributes are investigated in relation to social media banking in this paper.

\section{Background}

Some banks provide social media banking services and a few examples are discussed. Fidor bank in Germany has no physical branches and prides itself as the first bank to have an online only banking service. The bank only has an online presence and since its establishment in 2009 the bank has come up with innovative solutions such as the 'like for interest'. This means that the more likes the bank gets on Facebook the more the interest rate a bank customer gets on their savings rate and vice versa for their overdraft and loan rates.

Commonwealth Bank of Australia has a Facebook banking tool (CommBank Kaching app) that enables customers to make deposits and payments through Facebook app and also peer to peer payment using phone number and address. Barclays bank in the United Kingdom recently launched a payment system on Twitter called PingIt which allows bank customers to make payments via their Twitter accounts. Denizbank in Turkey prides itself as being the first bank to have a Facebook banking branch. It launched a Facebook application in 2012. Customers could transfer money through their Facebook accounts and could also monitor their current, savings and credit card accounts. Over 150000 people used the application within two weeks of its launch. In addition, customers can make credit applications through Facebook and Twitter and get special interest rates.

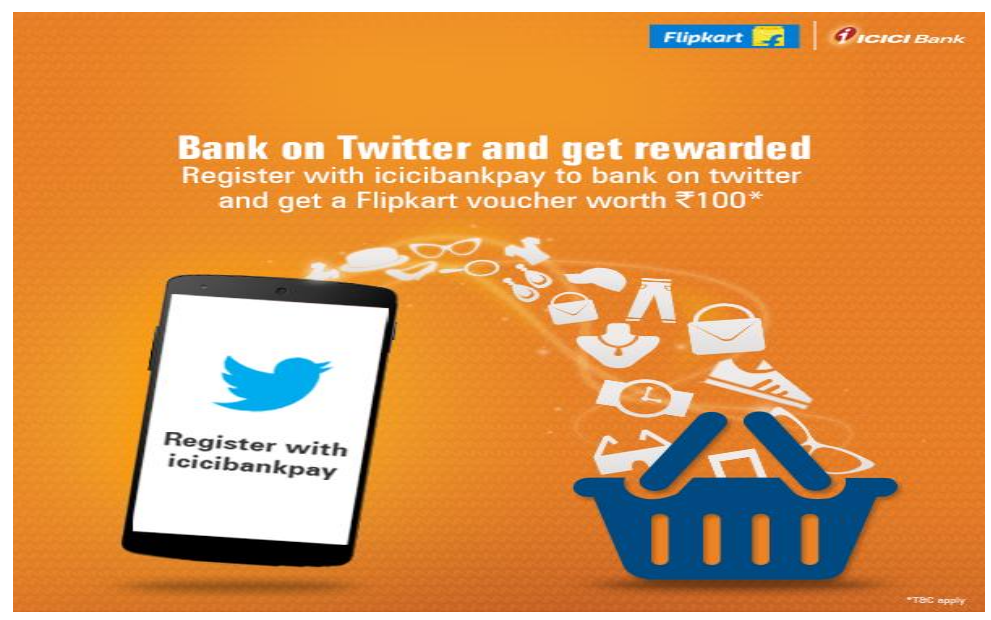

Fig 1: ICICI bank India advert for banking on Twitter

ICICI Bank India (Fig 1) allows customer to get bank account information through Facebook. A debit card and password is required to perform this transaction though. Customers can also make payments to anyone 
on the Facebook list of friends. In addition, the bank launched payment services on Twitter at the beginning of 2015. With this new service, customers can make payments to anyone who has a Twitter account, they can also check their account balance and last three transactions on their account.

Social media banking is relatively new and any idea that is perceived as new should be considered an innovation worthy enough to be studied. Few academic research is reported in the field of social media banking as it is relatively new and studies reported were limited to managerial perception of social media use [6], bank brand reputation and customer service through social media [5], social media strategies for banks [19] and adoption of social media marketing by banks [18]. There has been no research reported from the perspective of innovation adoption of social media banking services by the consumer hence the need for the present study.

Previous work has reported the use of the Diffusion of Innovation theory in the banking industry but this has only been for internet and mobile banking [2, 11, 12, 15, 17, 20]. Even though Internet and mobile banking are related and have made social media banking possible, there is still the need for more research as social media brings with it issues about privacy and trust, thus this present study was conducted to understand what customers attitudes are and what influences the adoption of this new technology .

\section{Theoretical framework and hypotheses}

In order to understand the factors that influence the adoption of a technology by consumers, it is essential to understand the theory that underpins how an innovation is adopted. There are existing models and theories that have been used to research the adoption of pre-existing technologies that existed before social media banking i.e. Internet banking and mobile banking. These theories include Theory of reasoned action, Theory of planned behaviour, Diffusion of Innovation theory and the Technology Acceptance Model and The Unified Theory of Acceptance and Use of Technology.

All of the above named theories have been used extensively with internet banking and mobile banking. For the purpose of this study, the diffusion of innovation theory will be reviewed as the focus of this study is investigating the attitudes and preferences of customers to adoption of social media banking with respect to the five attributes of diffusion of innovation theory. Everett Rogers in his book Diffusions of Innovation proposes that four main elements are responsible for the spread of new ideas namely communication channels, the innovation itself, time and a social system [16]. This approach in itself makes the research interdisciplinary as both the technicalities of the idea being proposed and the social system in which it would be used in would be considered, hence the reason for choosing this theory.

There has been research done investigating whether the attributes of diffusion of innovation theory have a relationship with the adoption of mobile and internet banking but none has been conducted on the use of social media by banks. The results of the previous studies on mobile and internet banking show that all of the attributes have a significant effect either positive or negative on attitudes towards adoption.

\subsection{Diffusion of Innovation Theory}

Definition of key terms that relate to the adoption of a new technology.

- Diffusion: The process by which a new product or idea is accepted by the users. 
- $\quad$ Rate of diffusion: The speed with which an idea or product innovation spreads amongst users.

- $\quad$ Adoption: The process by which a user accepts a new idea or product.

- Innovation: "An innovation is an idea, practice or object that is perceived as new by individual or other unit of adoption" [16].

\subsection{Attributes of Innovation}

The perceived attributes of innovation explain the rate of adoption of an innovation. These five attributes are relative advantage, compatibility, complexity, trialability, and observability. It is imperative to take into consideration the words of [16] which says "The individuals perceptions of the attributes of an innovation, not the attributes as classified objectively by experts or change agents affect its rate of adoption” (p. 223).

3.2.1 Relative Advantage: This is the degree to which an innovation is considered better than an existing alternative. It is assumed that the greater the degree an individual perceives relative advantage, the greater the rate of adoption of the innovation. Earlier research suggested that relative advantage of an innovation has a positive relationship with the rate of adoption of that innovation [13]. When a user perceives that the usefulness of a new technology over an existing one, they tend to adopt the new one (16). Previous research on the perceived correlation between relative advantage and mobile and internet banking showed a positive trend [2, 17]. As social media banking is an offshoot of internet banking, it is hypothesized that relative advantage will have a significant effect on attitude and the intention to adopt social media banking by customers.

H1: Relative advantage will have a significant effect on attitude towards social media banking adoption.

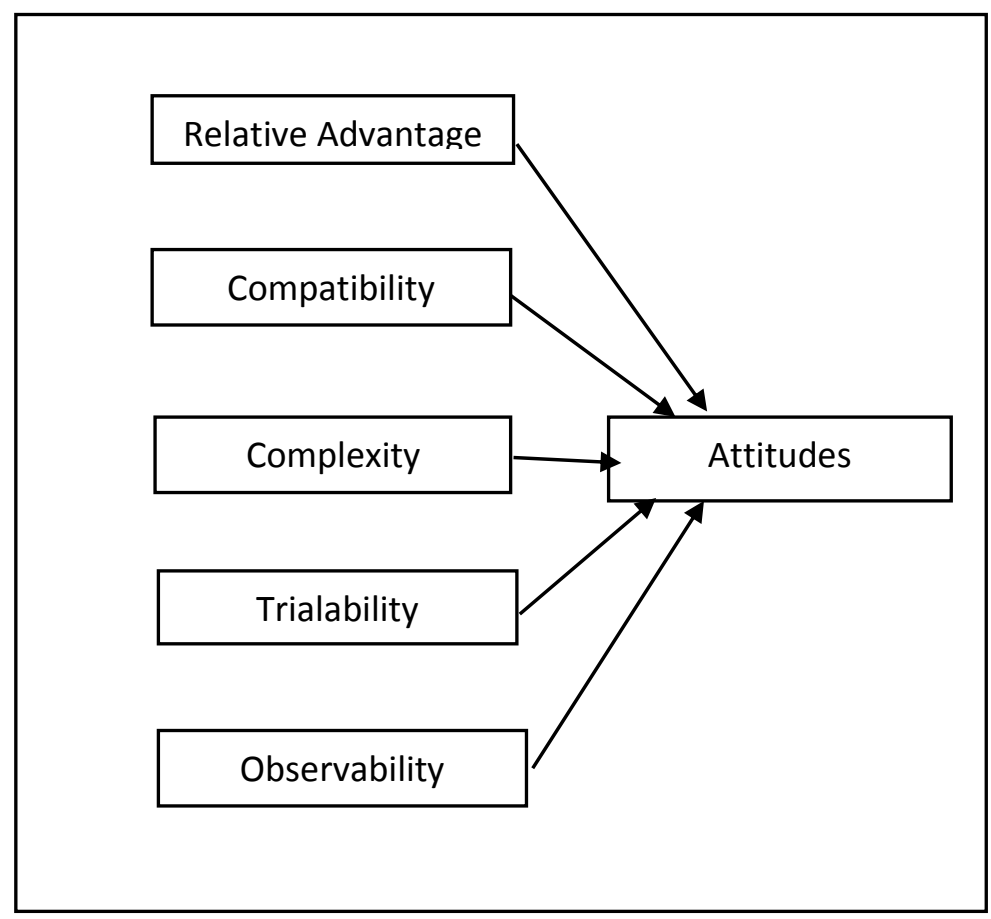

Figure 1: The research model 
3.2.2 Compatibility: This is the degree to which an innovation is consistent with existing values and past experience of adopters. It is assumed that innovations will be easily adopted if it fits an adopters existing values and experiences [16]. Previous research showed that compatibility is significantly relevant in the attitude of consumers towards the adoption of Internet banking [17]. Furthermore, it has been pointed out that perceived compatibility was statistically significant in the adoption of mobile banking [11]. Based on this review and on the premise that social media banking is an offshoot of both internet and mobile banking, it is hypothesized that perceived compatibility will have a significant effect on attitudes towards social media banking adoption.

H2: Compatibility will have a significant effect on attitude towards social media banking adoption.

3.2.3. Complexity: This is the degree to which an innovation is perceived to be difficult or easy to use. If an innovation is easy to understand then it would be adopted more than if it is complex to understand. [3] pointed out that perceived complexity influences the adoption of internet banking negatively. However [2] in their study on mobile banking adoption found that perceived complexity had no significant effect. Bank customers may not use social media banking services if it is frustrating or if it requires more effort than existing technologies (mobile and internet banking). Therefore it can be hypothesized that when a user perceives that an innovation is complex to use the less likely they are to adopt it.

H3: Complexity will have a significant effect on attitude towards social media banking adoption.

3.2.4 Trialability: This is the degree to which an innovation can be experimented with before actual use by the adopter. Rogers suggests that there is a faster rate of adoption of a technology if it can be tried before being fully implemented [16]. However [1] are of the opinion that this is not applicable to financial services as the user is not able to try the technology before implementation but previous research done on mobile banking and internet banking revealed that banks do provide demonstration tools on their websites which can be likened to being able to experiment the technology before actual use.

H4: Trialability will have a significant effect on attitude towards social media banking adoption.

3.2.5 Observability: This is the degree to which the result the outcome of the use of an innovation is visible to others [16]. This original construct was redefined into two constructs visibility and result demonstrability by [13]. With mobile banking, it was assumed that access to banking services anytime and anywhere without any delay and seeing the results of transactions makes it an innovation that that is perceived as being visible to others. The probability to adopt an innovation is higher when the benefits of using the innovation can be easily observed [4]. As the benefits of using social media banking can be easily observed by users, it can be hypothesized that perceived observability will have a significant effect on attitude towards its adoption.

H5: Observability will have a significant effect on attitude towards social media banking adoption.

\section{Methodology}

This research was exploratory in nature because there were no studies that provided an insight into consumers' attitudes and preferences for social media banking. For the purpose of this research, a quantitative approach was employed. This method was adopted as it is relatively quick to collect data and precise numerical data from quantitative research produce results which are independent of the researcher. A purposive sampling technique 
was used as this enabled specific group of people to be targeted in the study. The study was conducted in July 2015 and the target population was postgraduate students at the University of Southampton hence the small sample size of 107 as the undergraduates were on summer vacation and there were time constraints for data collection. The primary data for this study was collected using a structured questionnaire. The questionnaire had two sectionssection one comprised of questions to obtain information on the demographics of the participants and section two contained questions that collected data related to the influence of the five attributes of innovation on the perception and attitude of participants to social media banking. A 5 point Likert scale (a psychometric scale) was used and they were coded accordingly. The questionnaire consisted of 34 questions measuring five variables. Cronbach alpha index was used to check if multiple items in the questionnaire were reliable as well as to determine the internal reliability of the items for each construct. The coefficients ranged between 0.774 to 0.900 which implied that all the items in the constructs were reliable as they are all greater than 0.7 [8].

Data collected from the survey questions was analysed using Statistical Package for the Social Sciences (SPSS) version 22. Frequencies, means, standard deviations, multiple linear regression and correlation analysis are reported. The first section of the questionnaire (questions 1-10, 12-14) was analysed using descriptive statistics and the second section (question 11) was analysed using regression and correlation analysis.

\section{Research findings}

\subsection{Descriptive Statistics}

The total number of participants was 107 and demographics and descriptive statistics results showed that $52.3 \%$ of the participants were female and $47.7 \%$ were male suggesting that more females responded to the questionnaires. Majority of the participants were aged 18-25 and this is solely due to the fact that the survey sample is university students. Most participants $(n=48)$ preferred getting in touch with their bank in person compared to social media and other methods such as email. Only $8.4 \%$ of participants preferred getting in touch with their bank through social media. The results showed that $37.9 \%$ of participants used social media to view bank products and services, $25.3 \%$ had used social media to make bank payments and $24.1 \%$ to make complaints. Only a few customers $(n=3)$ had opened a bank account using social media. $25.3 \%$ of participants had actually made a payment using social media channels. $4.6 \%$ had not performed any of these activities. $10.4 \%$ of the participants reported that they would rather not use social media banking services but a good number (89.6\%) were happy to perform one activity or the other using social media banking. $79.4 \%$ of respondents indicated that data security was the most important factor that acted as a barrier towards their use of social media banking. The majority of respondents $(64.5 \%)$ were neither satisfied nor dissatisfied with social media banking which might have to do with the fact that majority of the respondents still preferred visiting a branch to perform their banking transactions. Only $31.8 \%$ of respondents were satisfied with their use of social media banking.

\subsection{Correlation Analysis}

Pearson correlation coefficient investigates the relationship between variables and measures the strength of an association between two variables. In this model, the level of significance was set at $1 \%$, the strength of association between relative advantage and attitude was very large $(r=0.885, p<0.01)$ while the strength of association 
between complexity and attitude towards social media banking is very low ( $\mathrm{r}=-.0 .317)$. Relative advantage, compatibility, trialability and observability all had positive correlations with attitudes to social media banking.

\begin{tabular}{|l|l|l|l|l|l|l|}
\hline & Attitude & \multicolumn{1}{l}{ Relative } & Compatibility & Complexity & Trialability & Observability \\
\hline advantage & & & & \\
\hline Attitude & 1 & 0.885 & 0.869 & -.0 .317 & 0.861 & 0.715 \\
\hline Relative advantage & 0.885 & 1 & 0.878 & -0.342 & 0.846 & 0.762 \\
\hline Compatibility & 0.869 & 0.878 & 1 & -0.367 & 0.842 & 0.757 \\
\hline Complexity & -0.317 & -0.342 & -.0 .367 & 1 & -0.304 & -0.217 \\
\hline Trialability & 0.861 & 0.846 & 0.842 & -0.304 & 1 & 0.679 \\
\hline Observability & 0.715 & 0.762 & 0.757 & -0.217 & 0.679 & 1 \\
\hline
\end{tabular}

Note: Correlation is significant at the 0.01 level

Table 1: Association between the constructs

\subsection{Multiple Regression Analysis}

Regression analysis was used to investigate the relationship between independent variables and a set dependent variables. In the present study, the independent variables were relative advantage, observability, trialability, compatibility and complexity whilst the dependent variable was the attitude to social media banking. The model was used to predict participants' attitude to social media banking. Table 2 below show the regression analysis results

\begin{tabular}{|c|c|c|c|c|c|}
\hline $\begin{array}{l}\text { Independent } \\
\text { Variable }\end{array}$ & $\begin{array}{l}\text { Unstandardized } \\
\text { Coefficient } \beta\end{array}$ & $\begin{array}{l}\text { Unstandardized } \\
\text { coefficient } \\
\text { Standard error }\end{array}$ & $\begin{array}{l}\text { Standardized } \\
\text { coefficient } \beta\end{array}$ & $\mathbf{T}$ & $\begin{array}{l}\text { Significance } \\
\text { Value }\end{array}$ \\
\hline Constant & 0.389 & 0.375 & & 1.039 & 0.301 \\
\hline Compatibility & 0.241 & 0.086 & 0.266 & 2.811 & 0.006 \\
\hline Complexity & 0.013 & 0.069 & 0.008 & 0.188 & 0.851 \\
\hline Trialability & 0.281 & 0.075 & 0.301 & 3.733 & 0.000 \\
\hline $\begin{array}{l}\text { Relative } \\
\text { Advantage }\end{array}$ & 0.368 & 0.090 & 0.389 & 4.096 & 0.000 \\
\hline Observability & 0.014 & 0.059 & 0.015 & 0.233 & 0.817 \\
\hline
\end{tabular}

Dependent Variable: Attitude

Table 2: Regression analysis results

The results (Table 3) showed that $84.2 \%$ of the variance in the dependent variable (attitude) is accounted for by the five independent variables. This suggests that the model is fit for use to measure the significance of the attributes of innovation on the users' attitude to social media banking. 


\begin{tabular}{|l|l|l|l|l|l|l|l|l|l|}
\hline Model & $\mathrm{R}$ & $\mathrm{R}$ & Adjusted & Standard & \multicolumn{2}{|l|}{ Change Statistics } \\
\cline { 5 - 10 } & & Square & R Square & $\begin{array}{l}\text { Error of } \\
\text { the } \\
\text { Estimate }\end{array}$ & $\begin{array}{l}\mathrm{R} \\
\text { Square } \\
\text { Change }\end{array}$ & $\begin{array}{l}\mathrm{F} \\
\text { Change }\end{array}$ & Df1 & Df2 & $\begin{array}{l}\text { Sig F } \\
\text { change }\end{array}$ \\
\hline 1 & $0.918^{\mathrm{a}}$ & 0.842 & 0.834 & 0.432 & 0.842 & 107.771 & 5 & 101 & 0.000 \\
\hline
\end{tabular}

a. Predictors: (Constant), Observability, Complexity, Trialability, Compatibility, Relative Advantage

Table 3: Model summary

The regression analysis also showed how statistically significant the five attributes of the diffusion of innovation are on the model and identified whether the independent variables significantly predicted the dependent variable. There was a strong relationship between the dependent and the independent variable $(\mathrm{R}=0.918)$. Observability and complexity recorded significance values of 0.817 and 0.851 respectively which were both greater than 0.05 which means these two attributes were not statistically significant. On the other hand, relative advantage, trialability and compatibility are statistically significant with values of $0.000,0.000$ and 0.006 respectively. The F statistic was very large $(\mathrm{F}=107.771, \mathrm{p}<0.005)$ and because the $\mathrm{p}$ value is less than 0.05 , the result is statistically significant. The equation that predicts the attitude to social media banking is represented by the model below.

$\mathrm{Y}=\beta 0+\beta 1 \mathrm{X} 1+\beta 2 \mathrm{X} 2+\beta 3 \mathrm{X} 3+\beta 4 \mathrm{X} 4+\beta 5 \mathrm{X} 5$

Where Y represents attitude and $\beta 0$ is the constant which has a value of 0.389 .

$\mathrm{X} 1=$ Relative advantage

$\mathrm{X} 2$ = Compatibility

$\mathrm{X} 3$ = Complexity

X4 = Trialability

X5 = Observability

Therefore the model is represented as

$\mathrm{Y}=0.389+0.368($ Relative advantage $)+0.281$ (Trialability $)+0.241$ (Compatibility)

\section{Discussion}

Findings of this study revealed that convenience and ease of use were the major incentives for the use of social media banking for participants. A third of the participants had made payments and viewed products and services using this channel. Few participants had opened a bank account using social media and perceived data security and privacy as barriers to adoption of social media banking indicating that security of transactions conducted on social media should be a priority to banks for attitudes towards the adoption of social media banking to improve. The study also found that participants were willing to receive financial advice and recommendations for products 
and services through social media banking as they found these to be more convenient to use even though they would still rather visit a physical branch to perform transactions. This highlights the need for awareness of social media banking services to be embarked upon by banks through other channels such as online and mobile banking so customers can be assured of getting the same form of service whether they visit a branch or virtually.

If customers perceive that social media banking is better than internet and mobile banking in terms of convenience and satisfaction, and perceive that it is consistent with existing values and can be experimented with before actual use, it would lead to an attitudinal change towards social media banking. Some participants reported that they preferred to have their social network accounts integrated with their bank accounts while others preferred to be able to apply for specific banking products through their social network accounts. Despite these positive perceptions, the majority of participants perceived data security and privacy as barriers to adopting this form of banking. Therefore issues of security should be of high importance to banks so they can reassure users of safety and increase their confidence in using social media banking. There is also the need for risk management policies to be put in place, for attitudes to change.

The regression results showed that relative advantage had a significant effect on the attitude of participants to use social media banking $(\beta=0.389)$. Pearson's correlation coefficient between relative advantage and attitude was a strong positive correlation and beta value for relative advantage was the highest among the independent variables which indicates that relative advantage had the highest contribution in explaining attitudes toward social media banking. Additionally significant positive correlations between attitudes to social media banking and relative advantage, compatibility, trialability and observability was observed, demonstrating the importance of these innovation attributes (Table 1).

The results showed that relative advantage, compatibility and trialability were statistically significantly associated with attitudes of participants towards social media banking. As of the time of writing this paper, there is a lack of literature on the influence of innovation attributes on attitudes to social media banking. Findings from this present study are however consistent with findings of [20] and [15] who reported that relative advantage, compatibility and trialability significantly influenced attitudes towards mobile banking adoption and internet banking adoption respectively.

\section{Conclusion}

This study set out to investigate students' attitudes and preferences for social media banking using the theoretical framework of the diffusion of innovation with particular emphasis on the five innovation attributes namely relative advantage, compatibility, complexity, trialability and observability. Findings from the study has demonstrated that students are aware of social media banking channels, though majority are neither satisfied nor dissatisfied with the service. Majority of the participants reported hearing about social media banking through word of mouth, so there is the need for banks to embark on sensitization through adverts, these adverts should highlight the benefits of using social media banking which could include convenience, ease of use and reduced time of transaction among others.

This study has generated insight into which innovation attributes are predictive of attitudes towards social media banking. The present study utilised an online survey method limiting participants to only internet users. Future work should incorporate using other technology models such as the Unified Theory of Acceptance and Use of Technology model to get a more comprehensive outlook into social media banking acceptance and 
adoption. Although this research has been based on data sourced from users and non-users of social media banking services, there can't be a generalisation of the result findings as the sample is not large enough therefore a study of non-users intention to adopt this form of banking should also be carried out with a larger sample.

\section{References}

1) Aldás-Manzano, J., Lassala-Navarré, C., Ruiz-Mafé, C., Sanz-Blas, S.: The role of consumer innovativeness and perceived risk in online banking usage. International Journal of Bank Marketing, 27(1), 53-75 (2009)

2) Al-Jabri, I. and Sohail, S.: Mobile banking adoption: Application of Diffusion of Innovation Theory. Journal of Electronic Commerce Research. 13(4), 379-391 (2012)

3) Chaipoopirutana, S., Combs, H., Chatchawanwan, Y. and Vij, V.: Diffusion of innovation in Asia: a study of Internet banking in Thailand and India. Innovative marketing, 5(4), 27-31 (2009)

4) Cruz, P., Barretto Filgueiras Neto, L., Muñoz-Gallego, P. and Laukkanen, T.: Mobile banking rollout in emerging markets: evidence from Brazil. International Journal of Bank Marketing, 28(5), 342-371. (2010)

5) Dalziel, N. and Hontoir, J.: A Tale of Two Banks: Customer Services on Facebook. Proceedings of 2nd European Conference on Social Media (ECSM2015), 9-10 July (2015)

6) Dănăiaţă, D., Margea, C., Kirakosyan, K. and Negovan, A.: Social Media in Banking. A Managerial Perception from Mexico. Timisoara Journal of Economics and Business, 7(2), 147-174. (2014)

7) Davis, F.: Perceived Usefulness, Perceived Ease of Use, and User Acceptance of Information Technology. MIS Quarterly, 13(3), p.319. (1989)

8) Field, A.: Discovering statistics using SPSS. 3rd edn. London: SAGE Publications. (2009)

9) Fishbein, M. and Ajzen, I.: Belief, attitude, intention, and behaviour. Reading, Mass.: Addison-Wesley Publishing Company. (1975)

10) Internetworldstats.com, European Union Internet Usage and Population Stats. [Online] Available at: http://www.internetworldstats.com/europa.htm\#uk (2015)

11) Khraim, S., Shoubaki, Y., and Khraim, A.: Factors affecting Jordanian consumers' adoption of mobile banking services. International Journal of Business and Social Science, 2 (20), 96-105. (2011)

12) Manoranjan, D., Pradhan, B. and Snigdha, S.: Determinants of Customers' Adoption of Mobile Banking: An Empirical Study by Integrating Diffusion of Innovation with Attitude. Journal of Internet Banking and Commerce, 19(3), 1-21. (2014)

13) Moore, G. and Benbasat, I.: Development of an Instrument to Measure the Perceptions of Adopting an Information Technology Innovation. Information Systems Research, 2(3), 192-222. (1991)

14) Murray, L., Durkin, M., Worthington, S. and Clark, V.: On the potential for Twitter to add value in retail bank relationships. Journal of Financial Services Marketing, 19(4), 277-290. (2014)

15) Nor, K., Pearson, M., and Ahmad, A.: Adoption of Internet banking: theory of the diffusion of innovation. International Journal of Management Studies, 17 (1), 69-85. (2010)

16) Rogers, E. M.: Diffusion of innovations, 5th edition New York: Simon \& Schuster Adult Publishing Group. (2003)

17) Tan, M. and Teo, T.: Factors influencing the adoption of internet banking, Journal of the Association for Information Systems, 1(5), 1-44. (2000)

18) Tarabasz, A.: The Use of Social Media in the Polish Retail Banking in the era of Marketing 3.0, University of Łódź, Poland. (2013) 
19) Taskiran, N. and Bolat, N.: Globalization and Social Media Strategies by Financial Institutions Worldwide. Managerial Issues in Finance and Banking, 67-76. (2013)

20) Yunus, M.: Diffusion of Innovation, Consumer Attitudes and Intentions to use Mobile Banking. Information and Knowledge Management, 4(10), 12-18. (2015) 